Public Policy in Britain 


\section{Public Policy in Britain}

Edited by

Stephen P. Savage

Rob Atkinson

and

Lynton Robins

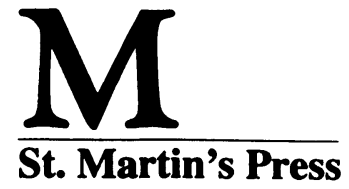


Selection, editorial matter and Conclusion @ Stephen P. Savage, Rob Atkinson and Lynton Robins 1994

Individual chapters (in order) $\odot$ Rob Atkinson and Stephen P. Savage; Stephen Cope and Rob Atkinson; Rob Atkinson and Stephen Cope; Fergus Carr and Stephen Cope; Mike Dunn and Sandy Smith; David Farnham and Carol Lupton; John Bradbeer; Mike Nash and Stephen P. Savage; Ian Kendall and Graham Moon; Rob Atkinson and Paul Durden; Malcolm McVicar and Lynton Robins; Neil Evans; Michael Hill; Arthur Aughey; Fergus Carr 1994

All rights reserved. No reproduction, copy or transmission of this publication may be made without written permission.

No paragraph of this publication may be reproduced, copied or transmitted save with written permission or in accordance with the provisions of the Copyright, Designs and Patents Act 1988, or under the terms of any licence permitting limited copying issued by the Copyright Licensing Agency, 90 Tottenham Court Road, London WIP 9HE.

Any person who does any unauthorised act in relation to this publication may be liable to criminal prosecution and civil claims for damages.

First published in Great Britain 1994 by THE MACMILLAN PRESS LTD

Houndmills, Basingstoke, Hampshire RG21 2XS

and London

Companies and representatives

throughout the world

A catalogue record for this book is available from the British Library.

ISBN 978-0-333-59597-8

ISBN 978-1-349-23444-8 (eBook)

DOI 10.1007/978-1-349-23444-8

First published in the United States of America 1994 by

Scholarly and Reference Division,

ST. MARTIN'S PRESS, INC.,

175 Fifth Avenue,

New York, N.Y. 10010

ISBN 978-0-312-12267-6

Library of Congress Cataloging-in-Publication Data

Public policy in Britain / edited by Stephen P. Savage, Rob Atkinson, and Lynton Robins.

p. $\mathbf{c m}$.

Includes bibliographical references and index.

ISBN 978-0-312-12267-6

1. Great Britain-Social policy-1979- 2. Policy sciences.

I. Savage, Stephen P. II. Atkinson, Rob. III. Robins, L. J.

(Lynton J.)

HN390.P83 1994

361.6'l'0941-dc20 
To

$N P S \& J P S$

Olive and Ken

$S J R \& M J R$ 


\section{Contents}

List of Tables $\quad$ ix

Preface xi

Notes on the Contributors xiii

PART I THE CONTEXT OF POLICY

1 The Conservatives and Public Policy Rob Atkinson and Stephen P. Savage

2 The Structures of Governance in Britain Stephen Cope and Rob Atkinson

3 Changing Styles of Governance since 1979 Rob Atkinson and Stephen Cope

4 Britain and Europe: From Community to Union?

Fergus Carr and Stephen Cope

\section{PART II SUBSTANTIVE POLICY AREAS}

5 Economic Policy under the Conservatives Mike Dunn and Sandy Smith

6 Employment Relations and Training Policy David Farnham and Carol Lupton

7 Environmental Policy: Past and Future Agendas John Bradbeer

8 A Criminal Record? Law, Order and Conservative Policy Mike Nash and Stephen P. Savage

9 Health Policy and the Conservatives Ian Kendall and Graham Moon 


\section{viii Contents}

10 Housing Policy since 1979: Developments and Prospects Rob Atkinson and Paul Durden

11 Education Policy: Market Forces or Market Failure? Malcolm McVicar and Lynton Robins

12 'A Poisoned Chalice?' Personal Social Services Policy Neil Evans

13 Social Security Policy under the Conservatives Michael Hill

14 British Policy in Northern Ireland: Between Activism and Consolidation Arthur Aughey

15 Foreign and Defence Policy under the Conservatives Fergus Carr

16 Conclusion: An Overview of Developments 


\section{List of Tables}

10.1 Main points of key housing legislation 184

10.2 Local authority dwellings completed in the UK, 1981-91 185

10.3 Sales of dwellings owned by local authorities and new towns in Great Britain, 1981-91 185

10.4 Housing Association dwellings built in the UK, 1981-91 188

10.5 Estimate of 'official homeless': actual and potential, 1990s, England only

10.6 Mortgage possession action statistics, 1988-93 (first quarter) (local authority and private) 


\section{Preface}

Public policy in Britain is currently at something of a cross-roads. In virtually every area of policy, but most particularly those areas which come under the umbrella of 'social policy' - health, housing, education, social security, personal social services and law and order - radical reforms are either under way or are at least on the political agenda. Fundamental shifts in the role of the state, and the redrawing of the former boundaries between 'public' and 'private' provision, are the order of the day. In an earlier publication (Savage and Robins, (eds.) 1990) an attempt was made to assess the impact of 'Thatcherism' on each of the main policy areas. On balance the conclusion then made was that, at the very least, that impact, in terms of the development of radical, New Right, policy reforms, was uneven and in some respects hardly apparent. In the contemporary political environment, however, it would seem hard to deny that radical reform is very much on the agenda. If anything the influence of New Right thought and ideology has been more in evidence since the departure of Margaret Thatcher as Prime Minister than before, this despite the relatively low key nature of political rhetoric which has characterised post-Thatcher Conservative leadership. The central concern of this book, therefore, is to assess the current status of public policy in Britain, against the backcloth of the political agendas of the Conservative Party as they have emerged since 1979.

The book will be divided into two parts. Part I will set out the 'contexts' of policy. It will discuss the more general developments in politics and policy which have set much of the scene for policy reforms in specific policy fields. Chapter 1 will consider the broader political basis of contemporary Conservatism, and some of the key ideological influences underpinning the politics of post-1979 Conservatism. Chapters 2 and 3 will address issues of 'structures' and 'styles' of governance since 1979 respectively, and the relationship between them and the agenda for public policy which has developed under the Conservatives. Chapter 4 will assess the impact of policy made within the wider context of the European Union on the domestic political scene. Taken together these chapters should make apparent some of the common threads which have run throughout separate areas of 


\section{xii Preface}

public policy, and the origins of such common threads in fundamental political developments in the governance of Britain under the Conservatives.

Part II of the book will proceed to discuss in detail key issues and developments in each of the major areas of public policy, in the light of the contextual matters addressed in Part I. While each of these chapters can to an extent be treated as 'stand alone' discussions of discrete fields of policy, a fuller appreciation of each will be only possible when coupled with an awareness of the broader themes considered in Part I. Furthermore, the reader is advised to study the parallels and similarities between the various areas of policy, for example, between health reforms and educational policy, or between housing policy and reforms in the personal social services. In the Conclusion an attempt is made to draw together some of the general themes which have cut across public policy since 1979, and to place these in the context of the future of public policy in Britain.

A 'Guide to Further Reading' is provided toward the end of the book which indicates some of the key references within the literature in each area covered in the book.

STEPHEN P. SAVAGE

ROB ATKINSON LYNTON ROBINS 


\section{Notes on the Contributors}

Rob Atkinson is a Senior Lecturer in the School of Social and Historical Studies, University of Portsmouth. Urban policy and urban change along with public policy are his primary research areas. He has published articles and chapters in books on these areas and has recently published (with Graham Moon) Urban Policy in Britain.

Arthur Aughey lectures in politics at the University of Ulster at Jordanstown. His primary area of research concerns politics in Northern Ireland, on which he has published widely. He is author of Under Siege.

John Bradbeer is a Senior Lecturer in Geography, Department of Geography, University of Portsmouth. His interests are in environmental planning and policy, with particular emphasis on natural resources and the coastal zone, rural planning, and leisure and recreation. He has published a number of articles and chapters in books on these areas.

Fergus Carr is Head of the School of Social and Historical Studies, University of Portsmouth. His primary research interests are contemporary strategy and international politics in the Middle East. He has published a number of articles and chapters in books on these areas.

Stephen Cope is a Senior Lecturer in the School of Social and Historical Studies, University of Portsmouth. His primary areas of research are local government and public policy, on which he has published a number of articles. He is currently completing a doctorate on 'cutback management in local government'.

Mike Dunn is Head of the School of Economics, University of Portsmouth. He has published widely in the field of resource economics and has published (with S. Cunningham and D. Whitmarsh) Fisheries Economics. 
Paul Durden is a Senior Lecturer in the School of Social and Historical Studies, University of Portsmouth. His primary areas of research are housing and educational policy; he has published mainly in the area of housing policy.

Neil Evans is a Principal Lecturer in Social Work in the School of Social and Historical Studies, University of Portsmouth. His current research interests include provision for the elderly.

David Farnham is Professor of Employment Relations at the University of Portsmouth. His publications include Personnel in Context, The Corporate Environment, Employee Relations (Institute of Personnel Management), Understanding Industrial Relations (with J. Pimlott) and Public Administration in the UK (with M. McVicar). He has also edited (with Sylvia Horton) Managing the New Public Services.

Michael Hill is Professor of Social Policy at the University of Newcastle upon Tyne. His primary areas of research are in social security policy and social policy, on which he has published widely. His publications include Social Security Policy in Britain, The Welfare State in Britain and (with Christopher Ham) The Policy Process in the Capitalist State.

Ian Kendall is Associate Head of School in the School of Social and Historical Studies, University of Portsmouth. His primary areas of research are social policy and health policy. He has published widely in both areas.

Carol Lupton is the Director of the Social Services Research and Information Unit (SSRIU) at the University of Portsmouth. She has published widely on the development of health and social care services and on unemployment and training policy. She has edited (with Terry Gillespie) Working with Violence.

Malcolm McVicar is Pro-Vice Chancellor of the University of Portsmouth. His primary area of research is education policy, and he has published a number of articles on this area. In addition he has published (with David Farnham) Public Administration in the UK. 
Graham Moon is Principal Lecturer in Health Studies in the School of Social and Historical Studies, University of Portsmouth. He has researched and published widely in the field of health policy and geographical information systems. His publications include (with $\mathbf{K}$. Jones) Health, Disease and Society and (with Rob Atkinson) Urban Policy in Britain.

Mike Nash is Senior Lecturer in Criminal Justice Studies, University of Portsmouth. He has worked previously at senior level in the probation service. His main research interests are in criminal justice policy, the probation service and offender 'seriousness', on which he has published a number of papers. He has also undertaken consultancy work with the Home Office.

Lynton Robins is Coordinator for Public Administration at De Montford University. $\mathrm{He}$ is co-author of Contemporary British Politics, co-editor of Two Decades in British Politics and editor of the Politics Association's journal, Talking Politics.

Stephen P. Savage is Director of the Institute of Police and Criminological Studies, University of Portsmouth. His primary research interests are criminal justice and policing policy, on which area he has published widely. He is also the author of The Theories of Talcott Parsons and co-editor (with Lynton Robins) of Public Policy under Thatcher; he is also editor of the International Journal of Sociology of Law.

Sandy Smith is a Senior Lecturer in Economics at the University of Portsmouth, and has a particular interests in the economics of central planning and market socialism, on which he has published a number of papers and articles. 